\title{
Moğollarda İstihbarat Faaliyetleri
}

Yavuz DELİBALTA*

\section{$\ddot{O} z$}

XIII. Yüzyıl başında Moğollar Cengiz Han liderliğinde askerî tarihin en büyük ve hızlı fetih hareketini başlattılar. Çin'den Orta Avrupa'ya kadar çok geniş bir sahada gerçekleşen büyük askerî seferlerle parlak zaferler kazandılar. $\mathrm{Bu}$ süreçte Moğolların başarı sağlamasındaki en önemli faktörlerden biri de istihbarat faaliyetlerine çok önem vermeleri ve iyi işleyen bir haber alma mekanizmasına sahip olmalarıydı. Moğol orduları herhangi bir seferden önce hedef bölgenin siyasî, askerî, sosyal ve ekonomik durumları hakkında her türlü bilgiyi toplamaya büyük özen göstermişlerdir. İstihbarat toplama sürecinde genellikle casuslar, tacirler ve elçilerden istifade edilmiştir. Hedef ülkelerde taraf değiştiren yahut devşirilen yerel unsurlar da istihbarat mekanizmasında önemli bir rol oynamıştır. Askerî sahada ayrıca keşif seferleri, öncü birlikler, gözcüler ve kılavuzlar vasıtasıyla ayrıntılı istihbarat çalışmalarında bulunulmuştur. Toplanan tüm istihbarî bilgilerin iletimi ve ordu birimleri arasındaki iletişim yam denilen hızlı bir posta sistemi sayesinde ok haberciler vasıtasıyla gerçekleştirilmiştir.

Anahtar Kelimeler: Moğollar, Moğol Ordusu, Cengiz Han, İstihbarat, Yam

\section{Intelligence Activities of the Mongols}

\begin{abstract}
At the beginning of the $13^{\text {th }}$ century, the Mongols under the leadership of Genghis Khan began the largest and fastest conquest movement in military history. They won brilliant victories in great military campaigns that took place in a very wide area from China to Central Europe. In this process, one of the most important factors involved in the success of the Mongols was that they attached great importance to intelligence activities and had a wellfunctioning intelligence mechanism. Before any campaign, Mongol armies took great care to collect all kinds of information about the political, military, social and economic conditions of the target region. They generally used spies, traders and ambassadors in the intelligence gathering process. Those local elements of target countries that changed sides or were recruited also played an important role in the intelligence mechanism. Besides, detailed intelligence studies were conducted in the military field through reconnaissance expeditions, pioneer units, observers and guides. The transmission of all intelligence gathered and the communication between army units was carried out by arrow messengers through a fast postal system called yam.
\end{abstract}

Keywords: Mongols, Mongolian Army, Genghis Khan, Intelligence, Yam (Jam)

Geliş/Received: 16.09 .2021

Kabul/Accepted: 30.12 .2021

- Bu çalışma, insanlardan veri ve örnek toplamayı gerektiren, anket, inceleme, alan çalışması ve deney içeren araştırmalar kapsamına girmediğinden etik kurul onay belgesi gerektirmemektedir.

\footnotetext{
* Arş. Gör., Kafkas Üniversitesi, Fen-Edebiyat Fakültesi, Tarih Bölümü, yavuzdelibalta69@gmail.com, ORCID: 0000-00015082-5498

(Makale Türü: Araştırma Makalesi)
} 


\section{Giriş}

İstihbarat kavramı sözlüklerde genel olarak "yeni öğrenilen bilgiler, duyumlar, bilgi toplama ve haber alma" olarak tanımlanmaktadır (Türkçe Sözlük I, 1998: 1107). İstihbarat faaliyetleri hedef ve hedef olması muhtemel unsurların güçlü ve zayıf yönlerini ortaya çıkarmak, harekât tarzları ve motivasyon durumları gibi hususlarda önceden doğru bilgi sahibi olabilmek amacıyla yürütülmektedir (İlter, 2002: 1-2). İstihbarat, tarihin her döneminde önemini korumuştur. M. Ö. VI. Yüzy1lda yaşayan Çinli filozof Sun Tzu, Savaş Sanatı isimli eserinde hükümdarlar ve komutanlar için istihbaratın önemini vurgulayarak zafere ulaşmanın buna bağlı olduğunu ifade etmiştir (Sun Tzu, 2008: 83-85).

XIII. Yüzyılda Moğol orduları büyük askerî seferlerle çok geniş bir coğrafyada tarihin akışını değiştiren sayısız zaferler kazandılar. Tarihin en önemli askerî liderlerinden birisi olarak kabul edilen Cengiz Han, 1206 yılında dağınık Moğol kabilelerini tek bir ulus halinde birleştirmeyi başararak Büyük Moğol İmparatorluğunun temellerini attı. Liyakate dayalı idare ve komuta kademesiyle disiplinli bir ordu ve esaslı bir devlet teşkilatı meydana getirdi. Askerî tarihin en büyük fütuhat hareketlerinden birini başlatan Cengiz Han, Kuzey Çin’i zapt ettikten sonra batıda Karahıtay ve Harezmşah İmparatorluklarına son vererek Türkistan ve İran'ın tamamını da hakimiyeti altına aldı. Komutanları Kafkaslar ve Karadeniz'in kuzeyine uzanarak parlak zaferler kazandılar. 1227 yılında Cengiz Han'ın ölümünden sonra onun mirasını devralan halefleri Ögeday (1229-1241), Güyük (1246-1248) ve Möngke (12511259) Kağanlar da büyük askerî seferlerle imparatorluk sınırlarını bir taraftan Orta Avrupa'ya diğer taraftan Hindistan, Anadolu ve Suriye içlerine kadar genişlettiler. Çin'de uzun yıllar devam eden savaşlar Kubilay Han (1260-1294) zamanında Güney Çin'in tamamen ele geçirilmesiyle sonuçlandı.

Moğol askerî başarısına etki eden amiller arasında ordu düzeni, katı disiplin, yetenek esaslı komuta yapısı, silah ve teçhizat kapasitesi, planlama ve stratejik üstünlük gibi unsurlar sayılabilir. Bununla birlikte şüphesiz zaferlerin arkasındaki en önemli unsurlardan birisi de istihbarat mekanizmasının işleyişidir. Moğol orduları herhangi bir seferden önce hedef bölgenin siyasî, sosyal, askerî ve ekonomik durumları hakkında her türlü bilgiyi toplamaya büyük özen göstermişlerdir (Martin, 2003: 58-59).

Bu çalışmada Moğol istihbarat faaliyetleri incelenerek siyasî ve askerî açıdan bilgi toplamak amacıyla başvurulan haber alma yöntemleri üzerinde durulmuştur. Bununla birlikte toplanan istihbaratın iletimi ve bilgi akışını sağlaması hususunda posta organizasyonuna da yer verilmiştir. Araştırma sürecinde genel tarih, vakayiname ve seyahatnâme türü birinci elden kaynaklar ve araştırma eserlerden istifade edilmiştir. Moğol fütuhatının çok geniş bir coğrafyayı kapsamasına paralel olarak tarihî kaynakları da bir o kadar çeşitlidir. Ancak kaynaklarda doğrudan konuyla ilgili ayrıntılı anlatımlar yer almamaktadır. Taramalar sonucu elde edilen veriler değerlendirilerek Moğol idarî ve askerî tarihî araştırmalarına katkıda bulunulması amaçlanmıştır. 


\section{Casusluk Faaliyetleri}

Moğollar herhangi bir seferden önce hedef bölgelere çok sayıda casus göndererek ayrıntılı istihbarat çalışmalarında bulunuyorlardı (Galstyan, 2017: 33). Moğol casusları, düşmanın askerî gücü ve devlet adamları arasındaki herhangi bir fikir ayrılı̆̆ı ve rekabet hususunda bilgi toplamaya çalışırlardı (Dvornik, 1893: 275). Bu casus ağları ayrıca savunmaları keşfetmek, yolları haritalamak ve tedarik kaynaklarını belirlemek için detaylı raporlar hazırlardı. Bu durum Moğolların düşmanlarından daha hazır bir savaşa girmelerini ve en iyi stratejiyi belirlemelerini sağlamıştır (Chambers, 1979: 60-62). Moğol casuslarına dair Parisli Matthew şunları belirtmektedir: "Her tarafa saldıkları ajanları ve hiçbir ilahi kanunları olmaksızın Mars'a özgü disiplinli karakterleri sayesinde uyumsuzluk içindeki devletler, tahkimat ve askerî olarak savunması bölgeler hakkında bilgi sahibi oluyorlar. Krallıkların sıkıntılarını ve kralların arasındaki çekişmeleri ögreniyor, zaman kaybetmeksizin hareketleniyor ve saldirıyorlar. Böyle bir yöntemi ne kadar övsen az!” (Özcan, 2013: 42).

Cengiz Han'ın daha ilk dönemlerden itibaren istihbarat faaliyetlerine büyük önem verdiği ve düşmanlarının durumundan çeşitli şekillerde haberdar olmaya çalıştığı bilinmektedir. Örneğin Kereyit hükümdarı Ong Han'ın ani saldırı ve suikast planını ona süt getiren iki çoban işiterek derhal Cengiz Han'a haber vermişlerdir. Cengiz Han, kendisine tehlikeyi haber veren Kişilik ve Baday isimli bu iki çobana daha sonra tarhan unvanı vererek onları ödüllendirmiştir (Moğolların Gizli Tarihi, 1986: 9192). Ong Han hizmetinde bulunan bu çobanların böyle bir haberi derhal ulaştırmış olmaları onların daha önceden Cengiz Han tarafına meyletmiş olduklarını ve onun hesabına casusluk yapmaları amacıyla görevlendirilmiş olabileceklerini düşündürmektedir. Bununla beraber ilk dönemlerden itibaren istihbarat sağlama noktasında daha ziyade tacirler ve elçilerden istifade edilmiştir.

Tacirler, Moğol istihbarat ve casusluk mekanizmasının en önemli unsurlarından birisi olarak görülmektedir. Uzak diyarlar boyunca pek çok kişi ve toplulukla temas kurmaları onları potansiyel bir bilgi kaynağı durumuna getirmekteydi (Delibalta, 2018: 90). Tacirler kâr kokusu aldıkları her yere hiç çekinmeden gidebiliyorlardı (Cüveynî, 1988: 135). Gittikleri iyi karşılanır ve itibar görürlerdi. Gözlem yetenekleriyle ticaret yaptıkları her bölgenin siyasî, ekonomik ve sosyal durumu hakkında çok önemli bilgiler edinirlerdi. Ticaretleri sebebiyle birçok bölgede temasları bulunuyor, İran'dan Çin'e kadar kervanlarının geçtiği tüm güzergâhları ve yolların durumunu iyi biliyorlardı. Ayrıca halk arasında çok geniş bir yelpazede propaganda yapma imkanına sahiplerdi. Cengiz Han en başından beri ticaretin önemini fark etmiş ve tacirlerle iyi ilişkiler kurmuştur. Zaman zaman onları kendi otağında ağırlayıp sohbet ederek çeşitli sorular sormuştur. Tacirler de han ile ilişkilerini geliştirmek ve kâr sağlamak amacıyla ona ihtiyaç duyduğu tüm bilgileri özgürce sağlamışlardır (Dvornik, 1893: 274-275). Moğollar özellikle Uygur tacirler vasıtasıyla Çin ile ticarî ilişkilere sahiptiler. 1211'de Kin seferinden önce bir 
Uygur tüccarı Moğollara bölgedeki şehirler ve halkları hakkında ayrıntılı bilgiler vermiştir (Shao Hung, 2012: 77).

Orta Asya ve Çin arasındaki tüm ticareti ise Müslüman tacirler kontrol ediyorlardı. Hiç şüphesiz Cengiz Han, Müslüman müşavirlerinin verdikleri haberlerden Harezmşah hakkında çok sağlam bir istihbarat edinmiştir (Barthold, 1990: 429). Bununla birlikte Cengiz Han, tacirlerin bu işleviyle yetinmeyerek onları aynı zamanda elçi ve casus olarak kullanmak yoluna da gitmiş̧ir. Nitekim, Buharalı, Harezmli ve Otrarlı üç Müslüman tüccarı Harezmşah Sultan Alâeddin'e elçi olarak göndermiştir. Bunlar aracılığıyla aradaki düşmanlığı alevlendirecek "Oğlum” hitabıyla sultana Çin’i zapt ettiğini haber vermiş ve aradaki ticareti geliştirmeyi teklif etmiştir. Ayrıca 1219'da Cengiz Han tarafından Harezm ülkesine gönderilen ve 400 Müslüman tüccarın yer aldığı ticaret kervanının Otrar valisi tarafından katledilmesinde de casusluk şüphesi bulunmaktaydı (Nesevî, 1934: 28-30). Moğol İmparatorluğunun her döneminde tacirlerden istihbarat amaciyla istifade edilmiştir. Kubilay Han da Venedik'ten ticaret maksadıyla gelen Marco Polo'nun babası ve amcasıyla görüştüğünde onlara hükümdarlarının kim olduğu, ordusunun ne kadar olduğu ve nasıl savaştıkları gibi sorular sormuştur. Polo kardeşler bu ve benzeri bilgileri Kubilay Han'a uzun uzun anlatmışlardır (Marco Polo Seyahatnamesi, 1990: 14). Daha sonra da Marco Polo, hanın hizmetinde elçilik görevinde bulunmuştur.

Moğol istihbarat kaynaklarının bir diğer önemli unsuru diplomatik vazifelerinin ötesinde casus olarak da görevlendirilen elçilerdir. Elçilere büyük önem verilerek hürmet gösterilmiş ve yolculukları boyunca her türlü ihtiyaçları karşılanmıştır (Shao Hung, 2012: 77; Carpini, 2018: 87). Nitekim Moğollar hem kendi elçilerinden hem de yabancı elçilerden istihbarat sağlama yoluna gitmişlerdir. Bu durum batılı elçilerin raporlarına ayrıntısıyla yansımıştır. Örneğin Güyük Han ile görüşen Papalık elçisi Plano Carpini, hanın onlarla beraber kendi elçilerini göndermek niyetinde olduğunu belirtiyor. Ancak o, yanlarında Moğol elçisinin gelmesini istemediklerini, çünkü onun ülkelerinde her an kavga ve savaş olduğunu görüp saldırı teklif edeceğinden korktuklarını ve ayrıca elçilik bahanesiyle casusluk yapacaklarından şüphelendiklerini ifade etmiştir (Carpini, 2018: 157). Aynı şekilde Batu ve Möngke hanlarla görüşen Fransisken rahip Wilhelm Von Rubruck da Moğol yöneticilerin kendisine ayrıntılı sorular sorduklarını detaylarıyla anlatmaktadır. Kendisine yöneltilen soruların onda, adeta üzerlerine yürüyerek her şeylerini alacakları kanaati uyandırdığını ifade etmektedir. Möngke Han, bu elçilerle birlikte kendi elçilerinin gitmesini de istemiştir. Rubruck, yanlarında gönderilecek Moğol elçisine yollara, şehirlere, kalelere, insanlara ve silahlara çok dikkat etmesinin emredildiğini ve gerçek amaçlarının casusluk olduğunu aktarmaktadır (Rubruck, 2019: 88, 94, 119, 123, 159, 166).

Moğol casusluk faaliyetleri tacirler ve elçilerle sınırlı olmayıp hedef bölgelere çeşitli kılıklarda casuslar da gönderilmiştir. Örneğin Kubilay'ın Mien'i fethinde casuslar çok önemli bir rol oynamıştır. Marco Polo'ya göre; saraydaki hokkabazlar, düzenbazlar ve oyunbazlar Mien'e girip casusluk yapıyor ve ortalığı kolaçan ederek olan biteni şehrin dışında pusu kurmuş Moğollara rapor ediyorlardı. Ona göre, 
eğer bu casuslar olmasaydı Mien fethedilemezdi (Marco Polo II, 1990, 9). 1299 seferinde Gazan'1n casusları da Memlük ordusunun her hareketini bildiriyorlardı (Hayton, 2015: 157).

Bununla birlikte çeşitli sebeplerle taraf değiştiren kimselerin yahut türlü vaatlerle devşirilen yerel unsurların da Moğol istihbarat mekanizmasında önemli bir rol oynadığı görülmektedir. Örneğin Çinli elçi Shao Hong; Kin hükümdarına gücenen dört memurun aileleri ve tâbiiyetindekilerle beraber Moğollara sığındıkları ve çok önemli istihbarat bilgileri aktardıklarını belirtmektedir. Bunun dışında Kin Hânedanı'na bağlı Ju Jun birlikleri de Moğollar tarafına geçerek ani saldırı ve taarruz planlarını haber verdiler. Moğollar casus gönderip haberin doğruluğunu tetkik ettikten sonra harekete geçtiler (Shao Hung, 2012: 76-77; D’Ohsson, 2014: 69-70).

Harezm seferinde ise Otrar'da Bedredddin isimli bir kaymakam sultana karşı olan şahsî husumetinden ötürü Cengiz Han ile görüşüp sultan ve ordusu hakkında çok kritik istihbarî bilgiler paylaşmıştır. Nitekim onun verdiği bilgiler sonucu kurnaz bir plan tertiplenmiştir. Harezm ordusundaki komutanların ağzından sanki Cengiz Han'a hitaben yazılmış sahte mektuplar kaleme alınmıştır. Mektuplar hülasa Harezmli komutanların sultandan ayrılmak ve Moğol ordusuna katılmak için emir beklediklerini ihtiva etmektedir. Bu mektuplar daha sonra firarî kılığına sokulan bir Moğol tarafindan sultana ulaştırıldı. Mektupları okuyan sultan en yakın komutanlarının ihaneti hususunda şüpheye düşmüştür. Nesevî’ye göre; bu durum sultanın askerlerini muhtelif mahallere dağıtmasının asıl sebebiydi (Nesevî, 1934: 31; Barthold, 1990: 432). Bunun dışında yine Harezm seferinde Nesa mutasarrıfı olan Ebû'l-Fetih de Moğollar ile anlaşıp daima onlarla haberleşmişti (Nesevî, 1934: 47). Otrar kuşatmasında Moğollar kendilerine sı̆̆ınan Karaca isimli Harezm subayından şehrin ne halde olduğunu öğrenmiş ardından efendisine ihanet ettiği için öldürmüşlerdi (Ebû'l-Ferec, 2011: 10). Velh kalesi kuşatıldığında ise kale reisinin oğlu Moğollara gelip kılavuzluk ve yol göstericilik yapmıştır (Cûzcânî, 2016: 71).

Aynı şekilde batı seferinde de benzer hadiselerin yaşandığı kaynaklara yansımıştır. Parisli Matthew'in eserinde yer alan mektuplarda Macaristan'da ele geçirilen İngiliz asıllı bir Moğol ajanından bahsedilmektedir. İtiraflarında belirttiğine göre, işlediği bir suçtan ötürü İngiltere’den kovulan bu kişi önce Orta Doğu'da Tapınak şövalyelerine katılmış ve daha sonra Moğollar tarafından hizmete alınmıştır. Moğollar birçok dil bilmesinden ötürü ajanları vasıtasıyla onu seçmiş ve kendisine pek çok hediye bahşetmişlerdir (Özcan, 2013: 48). Jan Dlugosz'un belirttiğine göre 9 Nisan 1241'de birleşik Polonya ve Alman ordusuyla gerçekleşen Liegnitz (Legnica) savaşında da Moğollar tarafından devşirilen Polonyalı bir asker hızla etrafta koşturarak Lehçe "koş koş" (ya da "kaç kaç") diye korkunç çığlıklarla bağırmış ve savaşın kritik bir anında Polonya ordusunda panik oluşmasına sebep olmuştur (Jan Długosz, 18). Bununla beraber Moğollar önünden kaçıp Macaristan’a sığınan mülteci Kıpçakların da aslında Moğol casusu oldukları yönünde şayialar çıkmıştır. Bu durum Moğol saldırısının hemen öncesinde Macar-Kıpçak ittifakının bir anda dağılmasına sebep oldu. (Roger, 2020: 154-158, 174-178). 
Her ne kadar söylentiler asılsız olsa da Moğol ordusunda daha başka Kıpçak unsurların yer alması bu şayianın Moğol casusları tarafından ortaya atıldığı izlenimini vermektedir.

\section{Askerî İstihbarat Faaliyetleri}

Moğol orduları askerî sahada da öncü birliklerle (karavul) keşif seferlerine çıkarak hem güvenlik tedbirleri alıyor hem de istihbarat topluyorlard1. Çinli gözlemcilere göre; "Moğollar kanat birlikleri dahil seçkin süvarilerden oluşan keşif birliklerini dört tarafa yollar ve yüksek bir yerden gözlem yaparlar. Keşif birlikleri bir veya iki yüz li (yaklaşı $50-100 \mathrm{~km}$ ) mesafelere kadar sefer yaparlar." Bu birlikler ayrıca yol boyunca kırsal yerlerde gözlem noktaları kuruyordu. Gönderilen casuslar aracılığıyla yolların ve şehirlerin durumu, konaklama bölgeleri, su ve otlakların konumu, savaşa uygun arazi ve düşman birliklerinin konuşlandığı alanlar gibi her türlü stratejik bilgi toplanarak rapor edilirdi. Düşman hakkında bilgi aldıklarında derhal birbirlerine aktarır ve dört tarafa çıkıp kontrole başlarlardı. Bilgi doğrulanınca ya da yeni bir güvenilir bilgiye sahip olduklarında aktarma istasyonları vasitasıyla hemen ana orduyu haberdar ederlerdi (Peng Da Ya ve Xiu Ting, 2012: 144).

Moğol ordusunun önemli bir unsuru olan yurtçi isimli yüksek rütbeli kurmay subaylar ana ordudan önce harekete geçerlerdi. Yurtçi subayları karargâh yerlerinin belirlenmesi ve kurulması, yolların açılması, otlak alanların tahsis edilmesi, lojistik destek ve iletişimin sağlanması yanı sıra keşif seferleri düzenlemek ve istihbarat toplamakla da vazifeliydiler (İgnatiyeviç, 1953: 27; Gabriel, 2017: 48). Plano Carpini de bu hususta destekleyici bilgiler aktarıyor. Ona göre, "Moğollar seferden önce bir öncü kıtasını kll çadır, at ve silahla donanmış olarak yollarlar. Bu grup düşmana saldırıda bulunup ganimet toplamaz. Rastladıkları insanları yaralar, öldürür ya da en azından korkutup kaçırırlar. Bu öncü grubunu esas ordu takip eder. Ayrıca komutanlar her tarafa akıncılar göndererek, saklanmış bulunan silahlı ve silahsız kişilerin yerlerini tespit ettirirler. Bunlar bu zor işlerde çok tecrübe sahibidirler." (Carpini, 2018: 103). Benzer şekilde C. de Bridia’ya göre, “Moğollar düşman ülkeye yaklaşmaya başladiğında bir şekilde terörü yaymak, öldürmek ve düşmanın kendilerine karşı beklenmedik bir hızla harekete geçmesini önlemek için en hızlı avcılarını ileri gönderirler. Hiçbir engelle karşılaşmazlarsa aileleriyle birlikte gizlenmeden ilerlemeye devam ederler." (C. de Bridia, 1967: 34-37; Skelton, Marston, Painter, 1965: 98-101).

Marco Polo ise keşif amaçlı iki yüz kişiden oluşan atı birliklerin ana ordudan önce çeşitli yönlerde iki günlük mesafeye kadar sefer düzenlediklerini ve düşmanın hareketini izlediklerini belirtiyor. (Marco Polo, 1990: 71). Dolayısıyla keşif devriyeleri ve izciler sayesinde düşmanın beklenmedik saldırılarından korunuyor ve arazi incelenerek düşmanın her hareketi gözlemleniyordu. Moğollar ayrıca kalabalık seferî kuvvetlerle çok uzak ülkeler hakkında da istihbarat toplamaya çalıştılar. Cebe ve Subutay'ın üç tümenlik kuvveti, Harezmşah'ı takipten sonra Hazar Denizi’nin kuzey kıyılarını ve batısındaki toprakları araştırmak, kimlerin yaşadığını öğrenmek ve ordularını test amacıyla üç yıllık keşif seferine çıktılar. Nitekim gönderilen casuslar ve bölgede kazanılan tecrübe sayesinde pek çok 
istihbarat toplanmış ve gelecekteki Avrupa seferinin planlaması buna göre yapılmıştır (Dvornik, 1893: 275-276).

Bununla beraber Moğol askerî istihbarat sisteminde k1lavuzlar ve izciler de önemli bir rol oynamıştır. Onların görevi orduya yollar, geçitler ve engeller hakkında bilgi vermek yahut rehberlik etmekti. Kılavuzlar genellikle coğrafyayı iyi tanıyan yerli halktan veya tacirlerden seçilmekteydi (Swietoslawsk1, 2002: 35). Örneğin; Oyrat seferinde iken Tutuka'nın adamları teslim olunca Cengiz Han onları kılavuz tayin etmiştir (D'Ohsson, 2014: 43,54). Harezm seferinde ise Kızılkum Çölü’nden geçerek Buhara'ya sürpriz bir saldırı gerçekleştirmek için bölgedeki göçebelere dostça davranıp onlardan kılavuzlar edinmiş ve bu sayede çölün gizli yollarından ordusunu geçirmeyi başarmıştır (Weatherford, 2009: 40). Bu hizmet karş1lığı menfaat sağlamayı arzu edenler olduğu gibi kimi zaman zor kullanarak da kılavuzlar bulunmuştur. İbnü'l-Esir'e göre Moğollar Şamahi şehrini ele geçirdikten sonra Şirvan derbendini geçmek istemişler fakat bir türlü geçememişlerdi. Şirvanşah'a elçi gönderip kendileriyle barış yapmak üzere bir heyet göndermesini istemişlerdir. Şirvanşah on kişilik bir heyet göndermiş ve Moğollar onlardan birini diğerlerinin gözü önünde derhal öldürerek diğer dokuzundan geçilecek yolları göstermelerini istemişlerdir. Durumdan korkan elçi heyeti bu derbentte dar bir yol hariç kesinlikle geçilecek bir yer bulunmadığını belirtmiş ve rehberlik ederek Moğolların bu dar yoldan derbendi aşmalarını sağlamışlardır (İbnü’l-Esir, 2008: 237).

Bunun yanı sıra bozkır orduları zaman zaman düşman hakkında bilgi verecek birini yakalayıp sorgulayarak dil alma olarak bilinen istihbarat sağlama yöntemine de başvurmuşlardır (Delibalta, 2018: 145). Moğollar da yakaladıkları esirlerden azami derecede istifade etmekteydiler. Çinli gözlemcilere göre, bazen yerli halktan birini yakalayıp etraftaki durum hakkında sağlam bilgiler alırlardı (Peng Da Ya ve Xiu Ting, 2012: 144). Örneğin Cebe Noyan, Küçlük üzerine sefere çıktığında Moğol askerleri Kaşgar halkından Küçlük hakkında bilgi istediler. Doğu Türkistan halkı Küçlük’ten nefret ettiği için bildiklerini isteyerek Moğollarla paylaşmışlardır (Barthold, 1990: 427). 1236 yılında II. Deşt-i Kıpçak Seferi esnasında da Möngke komutasındaki Moğol kolordusu Kıpçaklara saldırmış ve Kıpçak başbuğlarından Baçman kaçıp Volga kıyılarındaki ormanlara saklanmıştır. Moğollar Baçman'ın yerini terkedilmiş obada dil alma yöntemiyle sorguladıkları yaşlı bir kadından öğrendiler (Reşideddin Fazlullah, 1998: 326). Aynı şekilde Moğollar, Erzurum şehrine geldiklerinde de esir ettikleri birinden sultanın kalabalık bir orduyla yakın bir mıntıkada bulunduğuna dair bilgi almışlardır. İlhanlı komutanı Kutlukşah da Müslümanlardan bazı kimseleri esir alıp sorgulamış ve Memlük sultanı hakkında haberlere ulaşmıştır (Hayton, 2015: 85,172).

\section{Posta Organizasyonu (Yam)}

İstihbaratın toplanması kadar ilgili mercilere en hızlı ve güvenilir bir şekilde iletilmesi de bir o kadar önemlidir. Moğollar ilk dönemlerden itibaren belli mesafelerde kurulan gözlem noktaları aracılığıyla ana orduya hızlı bir bilgi aktarımı sistemi kullanmaktaydılar. Örneğin Cengiz Han ve Ong 
Han'ın Camuka'ya karşı savaşı sırasında Kerulen nehri boyunda ilerleyen öncü birlikleri yol boyunca gözlem noktaları kurarak toplanan istihbaratı derhal ana gövdeye aktarıorlardı. Bu sistemle, ana ordu ve kanat birliklerinin önünde ilerleyen karavul ve algıncı birlikleri $50 \mathrm{~km}$ 'den fazla mesafelerden elde edilen bilgileri ulaştırıyorlardı (Moğolların Gizli Tarihi, 1986: 70-71).

$\mathrm{Bu}$ yöntem zaman içerisinde genel bir uygulamaya dönüşmüştür (May, 2007: 70-71). Ordu ilerledikçe arkasındaki yol boyunca kurulan gözetleme noktaları sadece birlikler ve karargâhlar arasında değil aynı zamanda tüm ülke çapında teşkilatlı bir haber alma sisteminin uzantısı haline geldi (Chambers, 1979: 61-62) ve yam isimli posta organizasyonun temelini oluşturdu. Yaklaşık her 40-50 km'de bir "at direği” anlamına gelen yam istasyonları kurularak ülke çapında yüzlerce istasyondan oluşan büyük bir iletişim ağı oluşturuldu. Bir atlı birinden diğerine hiç duraklamadan dörtnala gidebilirdi. Yam istasyonlarında görev alan ve ok haberciler olarak adlandırılan ulaklar, görevlerinin öneminden ötürü en iyi atlara biniyorlardı. İstasyonlar; haberciler için yiyecek, barınak ve taze atlar sağlamaktaydı. Bir haber, herhangi bir istasyona ulaşır ulaşmaz yeni bir atlı onu bir sonrakine taşımak için hızla harekete geçerdi (Dvornik, 1893: 276). Bu sayede habercilerin istasyondan istasyona hızlı bir şekilde ulaşımı istihbarat toplama sürecini kolaylaştırdı.

Cengiz Han bu teşkilatı 1206 yılı kurultayından hemen sonra kurmuş ve birer günlük mesafe aralığında posta istasyonları kurulmasını emretmiştir (Kemaloğlu, 2017:56). Genellikle araştırmacılar Moğol posta teşkilatının kuruluşunda Çin etkisi üzerinde durmuşlardır. Ancak yukarıda belirtildiği gibi teşkilatın kökenini bozkır geleneklerinde aramak gerekir. Bununla beraber Cengiz Han'ın Çin'in kurumsal posta sisteminden de ilham aldığı ve yasalar çıkarıp fethedilen tüm topraklara yayarak teşkilatı daha da geliştirdiği savunulabilir (Dvornik, 1893: 277). Spuler, Cengiz Han'ın bu müesseseyi Çin ve İran'daki eski örneklere göre kurmaya muvaffak olduğunu belirtmekte ancak Moğol posta teşkilatının genellikle yenilikler içerdiğini ifade etmektedir. Ona göre; Moğol posta teşkilatının mükemmelliği bugün bile hayret vericidir (Spuler, 2011: 459).

Cengiz Han'ın emriyle belli yerlere menziller kurulup buralara yeterli sayıda at yerleştirildi. Menzillerin görevleri tespit edilip insan, hayvan, yiyecek ve araç gereç bakımından ihtiyaçları karşılandı. Yönetimleri o bölgede bulunan tümen komutanına verildi. Bu konak yerlerinden tüm gezginler, elçiler, kervanlar ve hanın koruması altında olanlar istifade edebiliyordu. İhtiyaçları ganimetlerden veya kopçur vergisinden karşılanırdı (Cüveynî, 1988: 101). Posta ve yam vergisinin miktarı noyanlar ve valilerin mevzuatına göre belirlenir ve kimse bundan muaf tutulmazdı (Peng Da Ya ve Xiu Ting, 2012: 125-126). Yerleşik bölgelerde posta teşkilatının kurulması ve istihbarat işlerinin yürütülmesi Moğol hakimiyetinin temsilcisi olan darugacilerin vazifeleri arasındaydı (Barthold, 1990: 426). Haberciler taşıdıkları özel payzaları ${ }^{1}$ sayesinde yol üzerinde herkesten yardım talep edebilir, atı

\footnotetext{
${ }^{1}$ Payza; Moğol İmparatorluğunda resmî görevlilere, elçilere ve habercilere kağan tarafından belirli imtiyazların verildiğini belirten yetki belgesi mahiyetindeki yazılı metal levhalardır. Çince “ $p$ 'ai-tse” kelimesinden türemiş
} 
yorulmuşsa yahut topalsa bir at talep edebilirdi. Atını veren kişi istasyona ulaştığında iadesi yapılırdı. Her istasyonda tek görevi yolları yönetmek olan memurlar ve devriye gezen askerler vardı (Chambers, 1979: 61-62).

Ögeday Han 1229 ve 1232 yıllarında posta hizmetiyle ilgili iki önemli yasa çıkardı. 1234’te Kin Hanedanı'na karşı kazanılan zaferden sonra bu meseleye özel bir önem göstermiş ve en önemli başarısının bu teşkilatı geliştirmek olduğunu belirtmiştir. Bu dönemde tüm imparatorluk topraklarında yeni yam istasyonları ve yollar yapıldı. Her bir istasyon için yirmi haberci tahsis edildi. İstasyonlarda bulundurulacak atların, yemek için kesilecek koyunların, sağılacak kısrakların ve koşulacak öküz arabalarının miktarı tespit edilip karara bağlandı. Bu yeniden yapılanma ile Kuzey Çin'in tamamından Çağatay topraklarına, oradan Volga'daki Batu Han ordasına kadar istasyonlar arası irtibat geliştirildi (Moğolların Gizli Tarihi, 1986: 203-204). Ögeday Han zamanındaki 1slahatlarla teşkilatın halkın sırtına yüklediği yük hafifletildi ve ulakların işleyişine bir düzen getirildi (Meriç, 2019: 53). Uzak coğrafyalarda bulunan hanedan üyelerinin büyük han ile düzenli haberleşmesi temin edildi. Kuzey Çin'den Karakurum'a Narin Yam isimli özel bir posta servisi de yalnız han için hizmet veriyordu.

Möngke Han da teşkilatın işleyişine büyük ehemmiyet gösterdi. Elde edilen gelirlerin bir kısmının posta sisteminin işleyişini geliştirmek üzere kullanılmasını emretti. Bazı suiistimallerden ötürü tacirlerin yam organizasyonundan istifade etmelerini yasakladı. Ulakların da meskûn mahallere girmemelerini emretti (Spuler, 2011: 459-460). Moğol posta örgütü en mükemmel halini Kubilay Han zamanında aldı (Dvornik, 1893: 285). Teşkilatın işleyişine şahitlik eden Marco Polo, haberlerin en hızlı şekilde ulaşması için Kubilay Han'ın posta işlerine çok önem verdiğini belirtiyor. Her 30 km mesafede at değiştirme ve dinlenme yerleri bulunuyordu. Onun zamanında her istasyonda üç yüz-dört yüz kadar at hazır bulunurdu. Toplamda iki yüz bin at ve on bin kişi bu işle vazifelendirilmiştir (Marco Polo I, 1990: 130-132).

Marco Polo'ya göre atlar istasyonların yakınındaki köy ve şehir halkından vergi karşılığı olarak sağlanırdı. Genellikle atların iki yüz tanesi istasyonda, diğerleri otlakta bulundurulur ve her ay bunlar değiştirilirdi. Eğer habercinin bir gölü geçmesi gerekiyorsa oraya komşu şehirler hızlı geçiş yapabilen üç-dört tekneyi daima hazır bulundurmalıydı. Birkaç gün süren bir çölü geçmesi gerekiyorsa çöl yakınındaki şehir halkı ona at ve yiyecek temin etmeli ve geçiş için eşlik etmeliydiler. Issız bölgelere ise han tarafından atlar sağlanırdı. Bu şekilde önemli bir istihbarat taşıyan atlı haberciler bir gün içinde 350-400 km'den haberleri ulaştırabilirdi. Haberciler özel görevlerinden ötürü tanınmak için göğüslerini ve kafalarını özel bir bandajla sarıyordu. Ayrıca ellerinde görevlerini belirten payza isimli tabletler bulunurdu. Bu şekilde en azami hızda seyahat etmesi gerekiyordu. Bir istasyona yaklaşırken uzun bir

olup Moğollara Çin’den geçtiği düşünülmektedir. Moğol payzaları siyasî ve askerî görevlerin yanı sıra posta hizmeti, ticaret ve seyahat gibi alanlarda kullanılmıştır. Payzalar verildiği kişinin rütbesine göre altın, gümüş ve demir levhalar olabilirdi. Ayrıca üzerlerinde türlerine göre aslan, kaplan ve pars gibi semboller bulunuyordu. Ayrıntılı bilgi için bkz. (Uzunçarşılı, 1988:202-206; Meriç, 2019: 41-47). 
süre duyulabilecek bir tür çan veya düdük çalar ve bunun duyulması üzerine istasyonda yeni bir at eyerlenerek hazır edilirdi. Yeni bir atlı vazifeyi devralarak süratle bir sonraki istasyona ulaştırırdı. Geceleri de haberler taşınıyor ancak meşaleler kullanmak zorunda kalınması ulakların hızlarını düşürüyordu. Ayrıca 4-5 km'de bir görev devretmek suretiyle yaya koşan postacılar da bulunuyordu. Bunlarda bellerine üzerinde çanlar bulunan geniş bir kemer takıyor ve bir sonraki istasyona ulaşır ulaşmaz yeni bir koşucu görevi devralıyordu. Bu sayede han, on günlük bir mesafeden gece ve gündüz haberler alırdı. Her istasyonda habercilerin varış gününü ve hareket saatini kaydeden bir kâtip bulunuyordu. Özel müfettişler her ay istasyonları denetlerlerdi. Marco Polo’ya göre, habercilerin mesaj taşımanın yanı sıra başka bir görevleri daha olup casus gibi hareket ederek seyahat boyunca gördüklerini ve duyduklarını aktarırlardı (Marco Polo I, 1990: 132-136; Dvornik, 1893: 291-293).

Marco Polo'nun posta örgütü hakkındaki bu bilgilerini XIV. yüzyıl seyyahları olan İbn Battuta (İbn Battuta, 2019: 615-628) ve Odoric Pordonene (Lee, 2015: 62) de teyit ederek desteklemeklemişlerdir. Nitekim geniş bir coğrafyada uzun süre aralıksız işleyen yam teşkilatı Altın Orda, İlhanlı ve Çağatay Hanlıklarında da en gelişmiş ve en etkili kurumların başında gelmekteydi (Kemaloğlu, 2017: 134-135; Spuler, 2011: 460; Kafal1, 2005: 66-67).

\section{Sonuç}

XIII. Yüzyılda Cengiz Han liderliğinde güçlü bir ordu ve sağlam bir devlet teşkilatı meydana getiren Moğollar, askerî ve siyasî mücadelelerin bir gereği olarak istihbarat faaliyetlerinde bulunmuşlardır. İstihbarat toplama sürecinde tacirler, elçiler, gönüllü muhbirler, devşirme unsurlar ve değişik kılıklarda gönderilen casuslardan istifade edilmiştir. Elbette tüm bu kaynaklardan istihbarat toplama Moğollara özgü yeni bir şey değildi. Fakat Moğolların bu kaynakları yoğun ve etkili bir şekilde kullanıp değerlendirme becerisi mükemmeldi. Casuslar vasıtasıyla hedef bölgelerin siyasî, askerî, ekonomik ve sosyal özellikleri hakkında ayrıntılı bilgiler toplanıyordu. Casuslar ayrıca asılsız haberler çıarma, söylenti ve şayia yayma usulüyle düşman ülkede geniş bir yelpazede propaganda ve dezenformasyon çalışmalarında da bulunuyorlardı.

Aynı şekilde askerî sahada keşif seferleri düzenlemek, öncü birlikler göndermek, kılavuzlar görevlendirmek ve esirler yakalayıp sorgulamak suretiyle istihbarat faaliyetlerinde bulunulmuştur. Hasım orduların durumu, asker mevcudu, silah ve teçhizat kapasiteleri, muharebe yöntemleri gibi kritik bilgiler toplanarak ayrıntılı raporlar hazırlanırdı. Arazi keşfi yapılarak savaşa elverişli alanların tespiti, yollar, geçitler ve köprülerin nitelikleri, su ve otlak alanları gibi coğrafi ve lojistik hususlarda da detaylı incelemelerde bulunulurdu. Elde edilen tüm istihbarat, belli mesafelerde konumlanan gözcüler ve aktarma istasyonlarıyla süratli bir şekilde ana orduya ulaştırılıyordu. Alınan istihbarat dahilinde askerî seferler planlanıyor ve stratejiler ona göre belirleniyordu. Tüm bu faaliyetlerin çok daha geniş alanlara yayılması ve başarılı sonuçlar vermesinde elbette Moğol askerî düzeni ve disiplin unsurlarının da büyük payı vardır. 
Devletin kuruluşundan itibaren yam adı verilen hızlı bir haber alma sisteminin temelleri atılmıştır. Yam sisteminin ana işlevi istihbarat akışını hızlandırmaktır. Kökenleri bozkır geleneklerine dayanan sistem Çin ve İran'daki örneklerinden hareketle daha da geliştirilmiştir. Fethedilen tüm bölgelere yayılarak istihbarat ağı genişletilmiş ve zaman içerisinde yapılan düzenlemelerle sistem mükemmelleştirilmiştir. Dönemin kaynaklarının verdiği bilgilerden Moğolların, çağdaşı olan diğer devletlerden çok daha üstün bir istihbarat mekanizmasına sahip oldukları anlaşılmaktadır. Hem casus ağları hem de haber iletiminin hızı, dönemde alışılanın çok üzerindeydi. Bu durum Moğolların üstün askerî başarılarının arka planındaki en önemli unsurlardan biri olarak görülmektedir.

\section{Kaynakça}

Alaaddin Ata Melik Cüveynî. (1988). Tarih-i Cihangüssa I. (M. Öztürk, Çev.). Ankara: Kültür ve Turizm Bakanlığ Yay.

Barthold, V. V. (1990). Moğol İstilâsına Kadar Türkistan, H. D. Yıldız, (Yay. haz.). Ankara: TTK Yay.

C. de Bridia Monachi. (1967). Hystoria Tartarorum. Alf Önnerfors (Ed.) Berlin

Chambers, J. (1979). The Devil's Horsemen, The Mongol Invasion of Europe. London: Book Club Associates.

D’Ohsson, A. C. M. (2014). Moğol Tarihi. E. Kalan (Yay. haz.). İstanbul: IQ Kültür Sanat Yay.

Delibalta, Y. (2018). Selçuklularda İstihbarat. İstanbul: Yeditepe Yay.

Długosz, J. Rocznıkı Czylı Kronıkı Sławnego Królestwa Polskıego, Księgi VII-VIII: (1241-1299). D. Turkowska-M. Kowalczyk (Ed.), (J. Mrukówna, Lehçe Çev.). Bilgisayar Sürümü: WWW.ZRODLA.HISTORYCZNE.PRV.PL

Dvornik, F. (1893). Origins of Intelligence Services. Rutgers Univercity Press.

Ebû Abdullah Muhammed İbn Battûta Tancî. (2019). İbn Battûta Seyahatnâmesi. (A. S. Aykut, Çev.). İstanbul: YKY Yay.

Ebu'l-Ferec İbnü'l-İbrî. (2011). Târîhu Muhtasari'd-Düvel. (Ş. Yaltkaya, Çev.). Ankara TTK Yay.

Gabriel, R. A. (2017). Yiğit Subutay, Cengiz Han'ın En Büyük Komutanı. (M. Tosun, Çev.). İstanbul: Tarih ve Kuram Yay.

Galstyan, A. G. (2017). Ermeni Kaynaklarına Göre Moğollar. (İ. Kemaloğlu, Çev.). İstanbul: Yeditepe Yay.

Hartog, Leo de. (2003). Cengiz Han, Dünyanın Fatihi. (S. Uzun, Çev.). Ankara: Dost Kitabevi.

İbnü’l-Esir. (2008). el-Kâmil fi't-Târih. C. X, (A. Özaydın vd., Çev.). İstanbul: Hikmet Neşriyat.

İgnatiyeviç, M. (1953). Cengiz Han ve Timurlenk Devirlerinde Moğol-Tatar ve Orta Asya Milletlerinin Harb Sanatı ve Fütuhatları. (B. Kuban-S. F. Gökçaylı, Çev.). Ankara: E.U. Basımevi.

İlter, E. (2002). Milli İstihbarat Teşkilatı Tarihçesi, Ankara.

Kafalı, M. (2005). Çă̆atay Hanlı̆̆ı (1227-1345). İstanbul: Berikan Yay.

Kemaloğlu, İ. (2017). “Altın Orda Devleti”. Avrasya 'nın Sekiz Asrı: Çengizoğulları kitabı içinde (s. 98149). İ. Kemaloğlu ve H. Alan (Yay. haz.). İstanbul: Ötüken Yay.

Kemaloğlu, İ. (2017). "Büyük Moğol İmparatorluğu”. Avrasya'nın Sekiz Asrı: Çengizoğulları kitabı içinde (s. 29-67). İ. Kemaloğlu ve H. Alan (Yay. haz.). İstanbul: Ötüken Yay.

Korykoslu Hayton. (2015). Doğu Ülkeleri Tarihinin Altın Çağı. (A. T. Özcan, Çev.). İstanbul: Selenge Yay. 
Lee, Songja. (2015). Odoric Pordenone Seyahatnamesi (1318-1330). (Yayınlanmamış Yüksek Lisans Tezi). Marmara Üniversitesi Türkiyat Araştırmaları Enstitüsü, İstanbul.

Marco Polo Seyahatnamesi, I-II. (1990). F. Dokuman, (Yay. haz.). İstanbul: Tercüman 1001 Temel Eser.

Marco Polo. (2019). Dünyanın Hikâye Edilişi Harikalar Kitabı. (I. Ergüden-Z. Z. İlkgelen, Çev.). İstanbul: Ötüken Yay.

Martin, H. D. (Apr. 1943). "Mongol Army" The Journal of the Royal Asiatic Society of Great Britain and Ireland. No.1.

May, T. (2007). The Mongol Art of War, Chinggis Khan and the Military System. Pennsylvania: Westholme Publ.

Meriç, S. (2019). 13. Yüzyılda Moğol Posta Teşkilatı (Yam). (Yayınlanmamış Yüksek Lisans Tezi). Karadeniz Teknik Üniversitesi Sosyal Bilimler Enstitüsü, Trabzon

Minhâc-1 Sirâc el-Cûzcânî. (2016). Tabakât-ı Nâsırî, Moğol İstilasına Dair Kayıtlar. (M. Uyar, Çev.). İstanbul: Ötüken Yay.

Moğolların Gizli Tarihi. (1986). (A. Temir, Çev.). Ankara: TTK Yay.

Nesevî. (1934). Celâlüttin Harezemşah. (N. Asım, Çev.). İstanbul: Devlet Matbaası.

Özcan, A. T. (Aralık 2013). "Chronica Maiora'da Moğollara Dair Kayıtlar”. Tarih Okulu Dergisi, 6 (16), 23-77. http://dx.doi.org/10.14225/Joh336.

Peng Da Ya ve Xiu Ting. (2012). "Hei Ta shi lu”, M. Uyar (Yay. haz). (A. Danuu, Çev.) Cengiz Imparatorluğu Hakkanda İlk Tarih Kayıtları kitabı içinde (s. 95-165). İstanbul: Ötüken Yay.

Plano Carpini (2018). Moğolistan Seyahatnamesi. (E. Ayan, Çev.). İstanbul: Kronik Yay.

Reşideddin Fazlullah. (1998). Câmi 'ü't-Tevârîh I-II. (Açıklamalı İngilizce Tercüme: W. M. Thackston). Ş. Tekin-G. A. Tekin (Ed.) Harvard Üniversitesi.

Rubruck, W. V. (2019). Moğolların Büyük Hanı'na Seyahat. (E. Ayan, Çev.). İstanbul: Kronik Yay.

Shao Hung. (2012). "Meng Ta pei lu”, M. Uyar (Yay. haz.). (A. Danuu, Çev.) Cengiz İmparatorluğu Hakkında İlk Tarih Kayıtları kitabı içinde (s. 37-93). İstanbul: Ötüken Yay.

Skelton, R. A., Marston, Thomas E. ve Painter, George D. (1965). The Vinland Map And The Tartar Relation. New Haven And London: Yale University Press.

Spuler, B. (2011). İran Moğolları: Siyaset, İdare ve Kültür Illhanlılar Devri, 1220-1350. (C. Köprülü, Çev.), Ankara: TTK Yay.

Sun Tzu (2008). Savaş Sanatı. (A. Demir, Çev.). İstanbul: Kastaş Yay.

Swietoslawsk1, W. (2002). "The Organization of the Mongols' War Expeditions in the Twelfth And Thirteenth Centuries" Fasciculi Archaeologiae Historicae.

Torre Maggioreli Üstat Roger (2020). "Macaristan Krallığının Tatarlar Tarafından Yıkımı Üzerine Ağıt". Altay Tayfun Özcan, (Çev. ve Yay. haz.). Moğollar Avrupa'da: Moğolların Avrupa Seferinin $\ddot{U C ̧}_{\text {Tanığ }}$ kitabı içinde (s. 133-218). İstanbul: Kronik Yay.

Türkçe Sözlük I (1998). İsmail Parlatır vd. (Yay. haz.). Ankara: Türk Dil Kurumu Yay.

Uzunçarşı1ı, İ. H. (1988). Osmanlı Devlet Teşkilâtına Medhal. Ankara: TTK Yay.

Weatherford, J. (2009). Cengiz Han ve Modern Dünyayı Anlamak. (S. Karakale, Çev.). İstanbul: İnkılap Kitabevi Yay. 